\title{
PRESERVICE TEACHERS' STRATEGIES TO NEGOTIATE ENGLISH TEACHING PRACTICES IN THE REMOTE AREA
}

\author{
Febi Puspitasari, Joko Nurkamto, dan Diah Kristina \\ Faculty of Teaching and Educational Science, Universitas Sebelas Maret \\ email: febi.puspitasari@gmail.ac.id
}

\begin{abstract}
Conditions and facilities of English language classes in the remote area encourage the negotiation of learning to solve problems. This narrative research aims to reveal strategies of pre-service teachers of the SM3T program in the process of the negotiation of English language learning. The study used diaries and interview transcripts from four teachers from Pidie Jaya and Sumba. The findings showthat teachers use interpersonal (IPS) and instructional (IS) strategies in the negotiation process. In Pidie Jaya, IPS strategies consist of the use of local languages and the help of local people. Meanwhile, IS strategies comprise learning groups and introduction to learning activities. In Sumba, teachers make language adjustment and establish rapport and informal communication as IPS strategies and they carry out buddy teaching and assign homework as IS strategies. This study contributes to the intercultural approach to designing English Language Education programs for remote areas.
\end{abstract}

Keywords: EFL, remote areas, negotiation of learning

\section{STRATEGI GURU PRAJABATAN DALAM NEGOSIASI PEMBELAJARAN BAHASA INGGRIS DI DAERAH TERPENCIL}

\begin{abstract}
Abstrak
Kondisi dan fasilitas kelas Bahasa Inggris di daerah terpencil mendorong adanya negosiasi pembelajaran untuk menyelesaikan masalah. Penelitian naratif ini bertujuan untuk mengungkapkan strategi-strategi guru prajabatan program SM3T dalam proses negosiasi pembelajaran Bahasa Inggris. Studi ini menggunakan diary dan transkrip wawancara milik empat guru dari Pidie Jaya dan Sumba. Hasil penelitian menunjukkan bahwa guru menggunakan strategi Interpersonal (IPS) dan Instruksional (IS) dalam proses negosiasi. Di Pidie Jaya, IPS terdiri dari penggunaan bahasa lokal dan bantuan orang lokal. Sedangkan IS terdiri dari grup belajar dan pengenalan aktivitas-aktivitas pembelajaran. Di Sumba, guru melakukan penyesuaian bahasa dan membangun keakraban dan komunikasi informal sebagai IPS dan melakukan pengajaran dengan teman dan memberikan tugas rumah sebagai IS. Studi ini berkontribusi pada pendekatan antarkultur dalam merancang program Pendidikan Bahasa Inggris untuk daerah terpencil.
\end{abstract}

Kata kunci: EFL, daerah terpencil, negosiasi pembelajaran 


\section{INTRODUCTION}

Indonesian Government initiated a program of one-year teaching practice at remote areas in 2011-2017 named as SM3T (Scholar Teaching in Disadvantaged, Frontier and Outermost Areas) for fresh graduates in Teacher Education. The program was developed with the spirit that remote communities are believed to be able to develop the participants' social, emotional and pedagogy competences before entering Teacher Education Program (or Program Pendidikan Guru-SM3T, in Indonesian Language) to achieve their career as a professional teacher. The program successfully attracted the graduates in Teacher Education to get involved. According to the data of participants of SM3T from the Ministry of Education and Culture presented by Bintoro (2015), the number of English teachers is even the second highest number of the total of participants of SM3T (274 participants in 2011, 280 participants in 2012 and 302 participants in 2013).

During their pathway to be professional teachers, participants of SM3T (called as preservice teachers) inevitably experienced their best learning when they were sent to remote areas in which "problemrich activities" take place (Choi \& Hannafin, 1995). Preservice teachers experienced a meaningful authentic learning environment about how to link academic study to the real world of practice. Nevertheless, reality showed that what an educational theorists suggest were not easily implemented in remote classrooms.

According to the study entitled "When Theories Do Not Work Well: Voices From Former Young Teachers In
Remote Areas" (Nurhayati and Septia, 2017), preservice teachers argued that they cannot effectively apply all of knowledge and skills studied in the previous education during the teaching and learning process because of many limitations at remote areas. Their problems are enormous: problems with students, learning materials, language and learning environment and facilities.

Meanwhile, due to "the poor English exposure environment" (Passasung, 2005), most of remote areas in Indonesia do not have appropriate learning access such as internets, books and supporting teaching medias for familiarizing English subject.

Regarding these problems, preservice teachers ended up facing culture shock and being frustated (Nurhayati and Septia, 2017). Diah and Pradna (2012) in the earlier study also found that only one of three teachers in Sumba who has high resilience dealing with stress in teaching at remote areas.

It means that teaching English in a remote area is a challange in the sense that all theoretical knowledge in English Teaching Education goes haywire in the remote classroom. Moreover, preservice teachers are not trained earlier about rural education. Along the situation which cause them almost give up in the classroom, the duty must go on. At the end, the surviving teachers are the teachers who are able to adapt their teaching based on the local context. In this situation, preservice teachers are encouraged to find solutions in their classroom. When theories does not work well (Nurhayati \& Septia, 2016), preservice teachers utilize their social dialogue, critical thinking and their 
own ideas in order to "survive" in the classroom. Instead of depending on the theory of language learning, preservice teachers are encouraged to adjust their teaching based on the local context.

Therefore, a negotiation in classroom is needed to find effective ways of learning. The phenomenon of negotiated English teaching practices in remote areas is considered interesting. It certainly portrays the reality of education in Indonesia that teachers have to be ready with various types of students, learning environment and various ways to teach effectively.

Negotiation in the classroom can be considered as the reflection of sociocultural concepts of progressive education. It has something to do with the process on how the learning content is learned and how this learning is integrated with learners' experiences. Typically, the teacher and students get together for the purpose of acquiring knowledge or developing abilities. The idea allows students "to getinvolved in making choices and selection decisions with reference to curricular objectives, contents of the subject matter, in and out classroom activities, methodology, resources, materials, and means of assessment" (Yuksel, 2010 in Yu, 2015). Additionally, some parts are decided by the teacher. As an example, the teacher is responsible for leading students toward the engaging learning, a teacher arranges a syllabi according to the topics selected by students. ( $\mathrm{Yu}$, 2015).

It is critical to understand that there are many dimensions which influence negotiation. According to Fox (2009), negotiation is influenced by cultural factors such as power distance, individualism, masculity, uncertainty avoidance and long term orientatation among other. Thus, preservice teachers are considered as agents who open the dialogue with students about the appropriate education for them. It is as expected by Freire (1993, in Dale \& Hyslop-Margison, 2010) that preservice teachers should become "the agent which should bring transformative social decisions and reconsider what values constitute the social good". The study, then, is expected to uncover the preservice teachers' necessary strategies in negotiating teaching practices at remote areas.

\section{METHOD}

It is a narrative study with the purpose to understand experiences of preservice teacherin negotiating English teaching practice. Narrative inquiry is a methodology that "encompasses the interdisciplinary study of the activities involved in generating and analyzing stories of life experiences in the form of life histories, narrative interviews, journals, diaries, memoirs, auobiographies, and biographies" (Kim, 2008). Therefore, the data are yielded from in-depth interview transcripts and diaries. The sources of data in this study are in-depth interview transcripts and diaries.

The study involved four participants from two different remote settings in Indonesia. The two participants were preservice teachers (Teacher A and B) at Pidie Jaya, Sumatra Island while the others (Teachers C and D) were those at Sumba, Nusa Tenggara Island.

In terms of social context, two teachers at Pidie Jaya taught English at the same school in the developing 
region. Electricity and internet have been utilized in the school. The people uphold religious values and admire religious figures. As the consequence of the traditional influence the society perceived that religious learning was more important than learning other subjects.

At Sumba, Preservice teachers taught English at the school near of sea. There was limited power supply and there were limited use of high technology. Students were from lowincome families who worked as a farmer, a fisher, and a carpenter. They spoke three languages, namely Timor, Dawan and Indonesian languages. Most students had low number of attendance. Society had low knowledge about the importance of education.

They wrote diary in guided writing and free writing. The guided diary was to gather the basic information about the profile of participants, the cultural and social context, as well as the condition of school. The guided diary was given to the participants at their beginning of practices. Meanwhile, the free writing diary was used to gather information about classroom phenomenon meeting by meeting. They were asked to write free writing diaries for three months. Then, to yieldmore complete information, they were involved in-depth interview by using voice notes.

The data were analyzed by using narrative paradigm by Polkinghorne (1995) that the data were reformed into themes of descriptive story or taxonomies. Meanwhile, rechecking and adding research participants (Herdiansyah, 2010) was conducted to assure reliability. In terms of validity, triangulation was used by clarifying the data of a participant to other participants from one working place.

\section{FINDINGS AND DISCUSSION Findings}

According to the data, four respondents carried out two approaches in negotiation strategies: interpersonal approach (IPS) and instructional approach (IS). IPS deals with teachers' strategies to focus on the issue of relationship between the teacher and the students to make negotiation success. On the other hand, ISS are strategies of teachers to assist students to select appropriate learning strategies in the classroom.

In addition, the strategies are also divided based on two geographical contexts, namely the strategies of negotiation in the context of Pidie Jayaand that of Sumba.

In the context of Pidie Jaya, the teachers used IPS by learning the local language and asking a help of local people. The IS was using familiarizing language learning activities and learning groups.

In the context of Sumba, teachers used three strategies in IPS: (1) Rapport establishment, (2) language adjustment and (3) informal communication. Besides, instructional approaches in Sumba were implementing buddy teaching and familiarizing language exercises.

1. The Negotiation Process in the classroom at Pidie Jaya

1.1 Intepersonal Strategies (IPS)

1.1.2 Speaking the local language

At Pidie Jaya, the people mostly talked in the local language and they could not speak Bahasa Indonesia 
but just a little bit. Meanwhile, in the classroom the students were habituated to talk the local language without fully welcoming the new chance to talk in other language The condition inhibited the teachers who really needed to communicate with the students in the negotiation process. Preservice teachers were encouraged to adapt the culture of working area by learning the local language. The teacher could not force the students to listen to fully English class instruction

Reflecting to this condition, preservice teachers decided to speak their local language as the effort to be able to get their attention and to communicatively negotiate teaching practice in the classroom.

\subsubsection{Asking help of the local people}

Dealing with those stigmas, preservice teachers had a challenge to insert the new insight opposing the local people's stigma that English lesson is not an important subject for students to learn.

However, the teachers also realized that it was impossible to immediately change the mindset which had been created in years. Therefore, they needed local people but open-minded ones to approach to students. It was because the teacher could not instruct them anything in Indonesian language. In this case, They approached religious figures in the class and invited them joining the class, such as the classroom teacher and Islamic subject teachers.

\subsection{Instructional Strategies}

\subsubsection{Learning group}

In the respect of negotiation process, the communication occurred by having a group discussion among preservice teachers, the classroom teacher and the students. During a class, the first learning group was aimed to collect information about the students' problems and opportunities in English learning. The second discussion was to invite students to talk about their learning interest.

The first group learningwerethe high achievers learning discussion. Low achievers were not involved since it was hard for the classroom teacher to ask them to participate. They were asked to express their view about topics in the predesigned syllabus and their view about English.

This discussion focused on yielding information about students' interest and inviting students' participation in choosing the topic at English lesson. Based on the discussion, the agreed to have topics such as farm animals, public places, social media and digital communication.

It was also found that the students also preferred to make a group with their only close friends to the smarter ones. It was more comfortable for them to learn with their close friends.

\subsubsection{Familiaring Learning Activites}

Teacher A did it during two months. The learning activities were the modification involving the chosen topics by students. The students' involvementand responses during activities were used to value the effectiveness of the activity.

One of language learning activities was reading activities with the topic of public places. In the lesson, the teacher showed students a board of full of the symbols in public places. 
The teacher familiarized the students with the use of a board as the media for material presentation. In this phase, the teacher observed Students responses toward the use of board as the media of presentation. She found that The medium was attractive for them because of the use of colorful papers and pictures. It was noted by the teacher that the use of board was accepted in the English class.

Next, the teacher asked students to make a group of four and the students were asked to create their own notices as they found in public places. They were pleased to use scissors and glue and to draw pictures appropriately. This session was used by the teacher to observe the students' character and learning styles. It was found that they were able to learn in group as long as each member has his or her job description. Besides, they were comfortable to speak the local language in the group yet they were willing to learn how to communicate in English only in a small circle. The teacher, then, used board in other topics, namely daily activities. She also used a wall magazine in teaching recount and procedure texts.

2. The Negotiation Process in the classroom at Sumba

2.1 Interpersonal Strategies

\subsection{Establishing rapport}

It was a challenge for teachers that most students still perceived that the teacher was only an outsider who have different skin tone and appearance. On the other hand, Sumba people were mostly catholic so that the students found new things about people outside their local culture because the teachers are moeslems. Because it is rare for them to have teachers from urban cities, they were not brave to interact to her and him and to respond when the teachers asked them anything. It influenced beginning days of the teachers to find effective ways ofcommunication with students.

In following days, they faced difficulties to invite students to be active and participative both in the negotiation process. It was found by Teacher $\mathrm{C}$ and $\mathrm{D}$ from Sumba that physical punishment was habitually used to discipline young people. Elaborately, teacher B explained this unpleasant method affected to students who rather played safe by not expressing their feeling and thought in the class as well as by not participating in the teaching-learning process. They were not willing to do the task and to be assessed.

Then, they created the image as the teacher whom students liked and they could trust so that the teachers were able to attract students' willingness to work with them. Teacher C and D established rapport by eliminating physical punishment in the classroom.

\subsubsection{Language adjustment}

Language adjustment was the effort by teacher C and D to adapt their language by using the accent and dialect of local language. In daily life, teachers spoke Bahasa Indonesia with them. However, Bahasa Indonesia in the Sumba context is different in the aspect of accent and dialect from that language in common. Therefore, the teachers changed the accent and learnt the dialect to make students easily to understand the teachers' intention of communication. 
It was observed that language adjustment by teachers succeeded to initiate the mutual understanding between the teacher and students. The teachers found it easier to convey their message and to instruct them to do something in their adjusted accent and dialect of Bahasa Indonesia. At the same time, they also opened the chance for students to share their feelings and opinion in their typical language. The teachers get students' characteristics in learning a new language in such a way how they used the language, Bahasa Indonesia.

\subsubsection{Informal communication}

Teachers adjusted themselves to establish relationship out of classroom. They took advantages of break time and school activities to approach them. They also welcomed students to interact to them about English or other lessons. Moreover, they opened a private class to give students a chance to consult their difficulties to the teacher. Surprisingly, students came to the teacher by their own willingness.

Despite of the positive effects, there was a drawback for being a nice teacher in the rude environment. The smaller gap between the teacher and students was misinterpreted in some cases that the teacher was treated as just a friend.

As the consequence, they thought it was not a problem to not show them respect to the teachers.

Interpersonal approach by the teachers affected three things: 1) students were more convenient to share their difficulties of learning and to learn a language, 2) students were easier to accept new things, 3 ) those were easier for teachers to deliver their messages and to negotiate English teaching practices with students.

\section{2 Instructional Strategies}

2.2.1 Implementing buddy teaching

Students needed assistance to communicate their problems and interest in English learning. However, Teacher $C$ realized that she could not directly open the communication with low achievers. They even had no idea to learn what they favored. To deal with problems, teachers decided to invite the high achievers to help them approaching students who were difficult to talk. High achievers were invited to assist their friends, to open the safer place to their friends talking about their problems dealing with their learning at shool, and to find the good pattern of team learning.

When they were willing to do something in the classroom, the teacher expected to find the silver line of their learning interest and their needs in English lesson. The teacher set a secure situation for low achievers to express themselves in the learning process. It was aimed at observing disengaged students' problems and their personal interest. As quoted in the interview transcripts, the teacher found that they were disengaged in writing activities. On the other hand, she found that they like arts. The teacher negotiated by herself that she should accomodate the students' interest. The designed situation of secured learning atmosphere was supported by the role of high achievers. In pairs, high achievers were very helpful for low achiever. they did not show that they had to compete to each other to be the best at class. Moreover, they helped their friends to memorize materials. 
According to an interview with the teacher, high achievers also developed the new way to learn. When they did not understand a material, they surely could not help their friends. Therefore, they learned the material seriouly and learned to assisted their friends.

\subsubsection{Utilizing Homeworks}

Teachers in Sumba contemplated that they would get more information and idea to solve problems in the English class whether the students were invited to experience, to feel and to compare different and various learning activities. The purposes of familiarizing learning activities were to maintain the curiosity and the enthusiasm of the students while to be the chance for teachers to negotiate with students to do the teachers' instruction, especially about their task completion time. Meanwhile, it was also to encourage students' to be brave giving their opinion about the preference of techniques of teaching and strategies of learning.

I negotiated with the students when

I got them enthusiastic with learning activities today. I thought it was the right time to give them a homework. I asked them to complete their homework and I promised them to have another activities they liked. (IT Teacher C-Sumba)

The study shows that there are five aspects of negotiated pedagogical practices in Sumba, namely learning objectives, language of classroom instruction, choices of topics and choices of classroom activities and there are four aspects of negotiated pedagogical practices in Pidie Jaya, namely language of classroom instruction, choices of topics, choices of classroom activities and the type of assessment.

\section{Discussion}

Based on findings, cultural factors influence how teachers approach the negotiation process. Preservice teachers and students were from different cultural background and it is possible to have interpersonal conflict between the teacher and students. Therefore, the cross-cultural treatment in negotiation process are unique.

As shown in the result, the approach based on cultural factors in Pidie Jaya and Sumba are different. The influence of culture on negotiation is also stated by Morris and Fu (2001). Elaborately, the influence on culture on negotiation depended on the task that conflict presents, the social context, and the origin state of the teachers and students. Therefore, it is significant to carry out the interpersonal approach in the negotiation process at remote classroom.

People of Pidie Jaya are considered to have a tendency of the temperamental characteristics. They also only make a friend with people who are from their tribes or who have similar appearance to them. The culture of people from Pidie Jaya tosocialize defines their perceptions of themselves, and the manner they interact with others (Singh and Singh, 2014). They perceive that they are the master in their home and they restrict how close the relationship to people from other tribes and culture. Thus, the interpersonal approach is importantly used by preservice teachers to be accepted by students and to minimize the personal conflicts in the negotiation process, namely by using the local language and the assistance of local teachers to approach them. 
Dealing with the assistance of local to approach students, Teachers at Pidie Jaya showed low confidence to rely on their own effort. It related to their inability to communicate with students in the local language while at the same time, they needed for closure in the limited time. They dealt with their anxiety by allowing others to interfere their process of negotiation with students. In the positive view, it showed that preservice teachers implemented cross cultural management (Singh and Singh, 2014) which has a role in developing the different stages of negotiations, namely understanding self (being conscious with strength and weakness), being prepared by understanding the interest of different negotiating parties (using the assistance of local people) and understanding the consequences of failure of negotiation.

Speaking their local language is the strategy of preservice teachers at Pidie Jaya. According to Malhotra (2004), it is important for negotiators to speak one another's language. It means catching the nuances and cultural implications behind what is being said, and noticing how the other side uses words to convey ideas. By taking the time to understand the other party's history, culture, and perspective, teachers send the message that they will commit to the negotiation and the relationship - an integral step in trust building. This fluency also signals teachers' readiness to follow through on the negotiation.

At Sumba, teacher-centered approach was strongly embedded in the school. Students were very passive and the teachers is at the position of the higher power than students in which unreachable for students to communicate. Therefore, the interpersonal approach was important in Sumba to minimize the communication barrier between the teacher and students. The approach is minimizing the power gap between the teacher and students, namely by using their accent of language, eradicating physical punishment in the classroom management and interacting with them in the informal setting. It means that negotiation cannot neglect the significance of relationship between teachers and students to make negotiation success. Teachers thought that it was better to establishing trust between the teacher students to prepare them in the negotiation.

The importance of establishing trust in negotiation process were also supported by the finding by Fell (1993) who argued that trust between the negotiator and receiver is the feature of the effective and productive work relationships. He argued that a lack of trust is often suggested as the cause of disputation and of an inability to work through problems to satisfactory solutions.

Besides, teachers used the instructional strategies in approaching negotiation process. Based on findings, the strategies were used as tactics to maintain ongoing dialogue to engage their students in sharing their thought and interestinEnglishlearning whilestill maintaining content and pedagogical authority. It was found that learning group discussion were used by teachers at Pidie Jaya and Sumbato study the behavioral and attitudinal responses of students about English lessons.

In bussiness, group discussion is to learn the responses of candidates in the 
selection process. In teaching learning process, group discussion is the learning activities. However, in the negotiation, it is to learn the responses of students in learning. The responses were both verbal and nonverbal. However, actions in negotiation are often ambiguous. It is in line with as Malhotra suggested (2004) that many concessions go unnoticed or unacknowledged. This may lead to confusion, resentment, or an escalation of hardball tactics and unaccommodating behavior of students.

The characters of students influence the type of grouping in Pidie Jaya and Sumba. At Pidie Jaya, teachers used forum group discussion while at Sumba, teachers used buddy teaching. Forum group discussion was used by teachers to create the situation that students did not only share their thought but also listen to others. Therefore, negotiation occurred as the conscious process. It is called as the interactive negotiation in Breen and Littlejohn (2000). Learning itself is also produced in the process of negotiation. During the process, the students get information, clarify whether they need it or not, repeat what they learn, and retell the information as they interpret.

At Sumba, teachers used buddy teaching as the learning group because teachers aimed to create the securing situation for students to share their thought. Theteachers observed students' activities in pairs. It is surely difficult for teachers to interpret students' responses but the help of high achievers is beneficial in gathering information about the process of negotiation occur in group learning. However, knowledge of students to understand their needs in English learning was limited which caused preservice teachers to mostly negotiate personally about what best for students. As an example, preservice teachers at Sumba could not gather the students' voices about the preference of learning topics because they said they had no idea about the interesting topics. Thus, the teacher determined the topics based on the issues related to the life of students at Sumba. As the result, the teachers in Sumba had to explore more options of negotiating their idealism of teaching and students' wants and interest by trial and error actions. It means the aspect of negotiation in remote areas mostly involve personal negotiation as formulated by Breen and Littlejohn (2000). They explained that personal negotiation is the interpretation of meaning from what a teacher read and heard. Teachers negotiated by themselves by using the potential meanings of the written or spoken text and meaning based on the experience. Personal negotiation made teachers faster in making decision. However, it also opened the chance of misinterpretation. However, the information of high achiever who communicated with teachers minimized the risk of interpretation.

Familiarizing teaching activities are the instructional strategy to facilitate students the variety of activities and exercises in choosing the appropriate English teaching. Breen and Littlejohn (2000) named it as practical experience to share understanding at appropriate moments about students' priority, their learning needs, their different preferred strategies and styles of learning. This practical experience generate interpretations about negotiated aspects 
in pedagogical practices. After getting information about students' needs and difficulties, the teacher respond it by making decision.

Finally, the findings portrayed the negotiated aspects of teaching at Sumbaand Pidie Jaya. Negotiated aspects at Sumba are namely learning objectives, language classroom instruction, choices of topics, choices of learning activities and assessment. Negotiated aspects in Pidie Jaya are language classroom instruction, choices of topics, choices of learning activities, and form of assessment.

Those findings were in line with suggestions of Breen and Littlejohn (2000) that negotiated pedagogical practices encompass four areas: the purpose of their work together (learning objectives), the content or subject matter of their work (materials), their various ways of working together (learning activities), and their preferred means of evaluation of the efficiency and of the work and its outcomes (assessment and evaluation).

\section{CONCLUSION}

The study is written to expose the process of negotiation which lead to decision making in English teaching at remote areas. Indonesia which consists of various cultural and social characters needs different treatment to approach the problems in English teaching practices. Interpersonal and instructional strategies by using cultural approach could not be neglected in approaching students for successfull communication and negotiation. By using those strategies, it is hoped that it contributes to the optimism constrasting any desperate assumptions that students in remote areas could no be involved in creating the appropriate English teaching and learning in remote areas.

\section{GRATITUDE}

The writer expresses gratitude to the preservice teachers in Sumba and Pidie Jaya for the ongoing time availability during the data collection. The gratitude are also given to Directorate General of Learning and Students Ministry of Research and Teachnology and the coordinator of Teacher Training Program in Medan State University, Yogyakarta State University and Makasar State University for permission and supports.

\section{REFERENCES}

Bintoro, Toto. (2015). Rekap Data SM3T dan PPG 2011-2015. Kementerian Riset, Teknologi, dan Pendidikan Tinggi.

Breen, Michael P and Littlejohn, Andrew. (2000). Classroom Decision Making: Negotiation and Process Syllabus in Practice. Cambridge: Cambridge University Press.

Choi, J.I \& Hannafin M., J. (1995) Situated Cognition and Learning Environments: Roles, Structures, and Implications for Design. Journal of Educational Technology Research and Development 43(2):53-69. January 1995.

Dale J and Hyslop-Margison EJ. (2010). Paulo Freire: Teaching for Freedom and Transformation: The Philosophical Influences on the Work of Paulo Freire. Dordrecht, The Netherlands: Springer.

Diah A. R, K \& Pradna P., P. (2012). ResiliensiGurudiSekolahTerpencil. Dalam Jurnal Psikologi Pendidikan 
dan PerkembanganVol.1.No.,02 Juni 2012

Direktorat Jenderal Guru dan Tenaga Kependidikan. (2017). Rekap Data SM3T \& PPG 2011-2016. Jakarta: Direktorat Jenderal Guru dan Tenaga Kependidikan. Jakarta: Kemdikbud.

Fell, D.E. (1993). Developing Trust in Negotiation. Journal of Employee Relation, Vol 15 No 1, 1993, pp 3345.

Fox, Kenneth H. (2009). Negotiation as a Post-Modern Process. Minnesota: University of Hamline.

Herdiansyah, Haris. (2010). Metode Penelitian Kualitatif untuk Ilmu-ilmu Sosial. Jakarta: Salemba Humanika

Kim Atkins. (2008). Narrative Identity and Moral Identity: A Practical Perspective. Routledge

Malhotra, Deepak. (2004). Risky Business: Trust in Negotiations. Harvard Business Publishing: Harvard.

Morris, Michael W and Fu, Ho-Ying. (2001). How Does Culture Influence Conflict Resolution? A Dynamic Constructivist Analysis. Stanford University. Social Cognition, Vol. 19, No. 3, pp. 324-349.

Nurhayati, L. \& Septia, S.D. (2016, 3-4 November). When Theories Do Not Work Well: Voices from Former Young Teachersin Remote Areas. Paper presented at theITELL 2016 Conference Proceedings: Teaching and Researching. Salatiga: Satya Wacana Christian University,.
Passasung, N. (2003). Teaching English In An "Acquisition-Poor Environment": An Ethnographic Example of $A$ Remote Indonesian EFL Classroom. A Published Doctoral Thesis. University of Sidney.

Polkinghorne, D. (1995). Narrative configuration in qualitative analysis. Qualitative Studies in Education, 8, 5-23

Singh,AmitKumar\&Singh,Mili.(2014). Cross Cultural Communications in Negotiations. Scholars Journal of Economics, Business and Management. Vol 1(5):203-207

Williams, Gwendolyn M. (2011) "Examining Classroom Negotiation Strategies of International Teaching Assistants," International Journal for the Scholarship of Teaching and Learning: Vol. 5: No. 1, Article 21.

Yu, Liang-Ting. (2015). Tapping into Students' Digital Literacy and Designing Negotiated Learning to Promote Learner Autonomy. Journal of The Internet and Higher Education Volume 26, Juli 2015, Pp 25-32. Retrieved from https://www. sciencedirect.com/science/article/ pii/S1096751615000226 